\title{
Practicalities of a reduced volume formulation of a C1-INH concentrate for the treatment of hereditary angioedema: real-life experience
}

\author{
John Dempster
}

\begin{abstract}
Background: Hereditary angioedema (HAE) due to C1 esterase inhibitor (C1-INH) deficiency is characterized by recurrent swelling attacks that can be life-threatening if left untreated. Prompt treatment is vital during acute attacks; plasma-derived $\mathrm{C} 1-\mathrm{INH}$ (Berinert ${ }^{\circledR}$ ) is one treatment currently licensed for the intravenous treatment of acute HAE attacks in adults, adolescents and children. A new, volume-reduced formulation, of C1-INH is currently available which aims to reduce the time to treatment, and provide greater convenience to patients and healthcare professionals. Here we compare the clinical experience of the reduced volume $1500 \mathrm{IU}$ vial with multiple $500 \mathrm{IU}$ vials.

Methods: HAE patients treated with C1-INH at the Royal London Hospital were selected to take part in this assessment. Included patients were aged 10-65 with moderate to severe HAE requiring high doses of C1-INH. The practicalities of the reduced $1500 \mathrm{IU}$ vial compared with multiple $500 \mathrm{IU}$ vials were assessed, including preparation and administration time, training to self-administer time and several quality of life aspects.

Results: Twenty-three patients participated in this study. Twenty-one patients were previously treated with C1-INH (Berinert ${ }^{\circledR}$ ) $500 \mathrm{IU}$ for 1-14 years prior to switching to the $1500 \mathrm{IU}$ vial format, two patients were naïve to C1-INH $\left(\right.$ Berinert $\left.{ }^{\circledR}\right)$. Preparation and administration of $\mathrm{C} 1-\mathrm{INH}$ (Berinert ${ }^{\circledR}$ ) $1500 \mathrm{IU}$ was faster than an equivalent dose with multiple $500 \mathrm{IU}$ vials (11 and $17 \mathrm{~min}$, respectively) and also required less time to train to self-administer (45 and $55 \mathrm{~min}$, respectively). Overall, patients rated the $1500 \mathrm{IU}$ vial format higher in all assessed aspects than the $500 \mathrm{IU}$ format, including preparation, administration, training, travel and storage. Nonetheless, reconstitution of the $1500 \mathrm{IU}$ vial was noted more difficult, requiring gentle mixing to fully dissolve prior to intravenous injection. Patients remained stable on C1-INH (Berinert ${ }^{\circledR}$ ) $1500 \mathrm{IU}$; two patients switched back to multiple $500 \mathrm{IU}$ vials due to headaches and preference for a larger volume.

Conclusions: The volume-reduced $\mathrm{C} 1$-INH concentrate (Berinert ${ }^{\circledR}$ ) $1500 \mathrm{IU}$ is a practical and convenient alternative to multiple $500 \mathrm{IU}$ vials for the treatment of HAE, which provides patients with more control and independence over their disease owing to a simpler to administer treatment.
\end{abstract}

Keywords: Hereditary angioedema, HAE, C1 inhibitor, C1-INH, Reduced volume, Quality of Life, Practicalities

*Correspondence: John.Dempster@bartshealth.nhs.uk

Barts Health, Grahame Hayton Unit, Ambrose King Centre, The Royal

London Hospital, Whitechapel, London E1 1BB, UK 


\section{Background}

Hereditary angioedema (HAE) is a rare autosomal genetic disorder caused by $\mathrm{C} 1$ esterase inhibitor (C1-INH) deficiency (type I) or dysfunction (type II) [1]. C1-INH is a serine protease inhibitor that regulates activation of several inflammation pathways. Specifically, C1-INH deficiency/dysfunction results in an excess production of bradykinin, an inflammatory mediator. As a consequence, patients suffer recurrent severe swelling (angioedema) of various body sites, such as extremities, face, tongue, abdomen and throat, which is characteristic of HAE [1]. While abdominal attacks can be excruciating, laryngeal swelling can result in hypoxic brain injury or even death by asphyxiation [1-3]. Therefore, prompt and straightforward treatment is vital during acute attacks. Furthermore, prophylactic treatment to prevent attacks, and to reduce their long-term frequency and severity, is important for those affected by frequent HAE attacks. Several treatments for acute HAE attacks are available, including plasma-derived C1-INH, recombinant $\mathrm{C} 1-\mathrm{INH}$, bradykinin receptor antagonist (icatibant) and plasma kallikrein inhibitor (ecallantide) (see Table 1). C1-INH is a highly effective and safe treatment for HAE, which can be used for both acute treatment and prophylaxis $[4,5]$. The safety and efficacy of prophylactic C1-INH was first demonstrated in a crossover study; prophylactic treatment with $25 \mathrm{U} / \mathrm{kg} \mathrm{C} 1$-INH every 3 days for 17 days decreased HAE symptoms scores by $>60 \%$ compared with placebo [6]. Further randomized, controlled clinical trials have demonstrated a $50 \%$ reduction in the frequency of HAE attacks following twice weekly dosing of C1-INH (1000 IU) [7].

C1-INH (Berinert ${ }^{\circledR}$ ) is indicated for the intravenous treatment of acute attacks in adults, adolescents and children. Until recently, C1-INH (Berinert ${ }^{\circledR}$ ) was only available in $500 \mathrm{IU}$ vial sizes with a recommended dose for the treatment of acute attacks of $20 \mathrm{IU} / \mathrm{kg}$ body weight [8]. Treatment of an HAE attack in patients weighing over $25 \mathrm{~kg}$ would require multiple $500 \mathrm{IU}$ vials; on average the majority of adults require three $500 \mathrm{IU}$ vials. This results in an extended preparation and infusion time and may delay the time to treatment in life-threatening emergency situations. Furthermore, the World Allergy Organization recommends that patients carry on-demand treatment for two attacks at all times [4]. As a result it may be necessary for patients to carry multiple vials; this may increase the burden of disease and lead to reductions in quality of life. A new formulation of C1-INH (Berinert ${ }^{\circledR}$ ) which has been licensed in the EU since 2015 aims to reduce the time to treatment, and provide greater convenience to patients and healthcare professionals. The $1500 \mathrm{IU}$ vial is 10-times more concentrated (500 IU/ $\mathrm{ml}$ instead of $50 \mathrm{IU} / \mathrm{ml}$ ) and has a lower reconstruction volume ( $3 \mathrm{ml}$ vs. $10 \mathrm{ml}$ ) than the $500 \mathrm{IU}$ vial [8], hence

\section{Table 1 Summary of HAE treatments}

\begin{tabular}{|c|c|c|c|}
\hline Drug & Administration & Indications & Adverse events $[1,22]$ \\
\hline Plasma-derived $\mathrm{C} 1-\mathrm{INH}^{\mathrm{a}}$ & Intravenous, subcutaneous & $\begin{array}{l}\text { Self-administration, acute } \\
\text { and prophylaxis }\end{array}$ & $\begin{array}{l}\text { Rare: anaphylaxis or thrombosis }{ }^{c} \\
\text { Theoretical: transmission of infectious agent } \\
\text { Uncommon: injection site reaction, hypersensitivity, nasophar- } \\
\text { yngitis, dizziness }{ }^{\mathrm{d}}\end{array}$ \\
\hline Recombinant human $\mathrm{C} 1-\mathrm{INH}$ & Intravenous & Acute & Uncommon: anaphylaxis \\
\hline Icatibant & Subcutaneous & Self-administration, acute & Common: local swelling, pain, pruritus at injection site \\
\hline Ecallantide & Subcutaneous & Acute (only US) & $\begin{array}{l}\text { Common: prolonged partial thromboplastin time } \\
\text { Uncommon: development of antidrug antibodies, anaphylaxis }\end{array}$ \\
\hline Tranexamic acid & Oral, intravenous & Prophylaxis & $\begin{array}{l}\text { Common: nausea, vertigo, diarrhea, postural hypotension, } \\
\text { fatigue, muscle cramps with increased muscle enzymes } \\
\text { Uncommon: thrombosis }\end{array}$ \\
\hline Androgens ${ }^{e}$ & Oral & Prophylaxis & $\begin{array}{l}\text { Common: weight gain, virilization, acne, altered libido, muscle } \\
\text { pains and cramps, headaches, depression, fatigue, nausea, } \\
\text { constipation, menstrual abnormalities, increase in liver } \\
\text { enzymes, hypertension, and alterations in lipid profile } \\
\text { Uncommon: decreased growth rate in children, masculinization } \\
\text { of the female fetus, cholestatic jaundice, peliosis hepatis, and } \\
\text { hepatocellular adenoma }\end{array}$ \\
\hline
\end{tabular}

\footnotetext{
${ }^{a}$ Berinert $^{\circledR}$ (IV), Cinryze ${ }^{\circledR}$ (IV), HAEGARDA ${ }^{\circledR}$ (SC)

b Berinert ${ }^{\circledR}$ approved for: self-administration, acute treatment in adults and pediatrics, short-term prophylaxis in adults and pediatrics (only EU); Cinryze ${ }^{\circledR}$ approved for: self-administration, prophylaxis in adults and adolescents, acute treatment in adults and pediatrics (only EU); HAEGARDA ${ }^{\circledR}$ approved (only US) for: selfadministration, prophylaxis in adults and adolescents

c Intravenous administration

d Subcutaneous administration

e Danazol, stanozolol and oxandrolone
} 
the volume of a standard 1500 IU dose in the majority of adults is reduced from $30 \mathrm{ml}$ to $3 \mathrm{ml}$. The aim of this report is to detail the clinical experience of the C1-INH $\left(\right.$ Berinert $\left.^{\circledR}\right) 1500 \mathrm{IU}$ vial compared with the $500 \mathrm{IU}$ vial.

\section{Methods}

\section{Patient selection}

Between November 2015 and July 2017 patients treated with C1-INH (Berinert ${ }^{\circledR}$ ) at the Royal London Hospital were selected to take part in this assessment. Patients with moderate to severe HAE requiring high doses of C1-INH were considered for this study because of the benefits of a reduced volume in these patients. All patients were asked to try the new formulation; none declined. This included four patients using C1-INH $\left(\right.$ Berinert $\left.^{\circledR}\right)$ subcutaneously off-label. Two pediatric patients and two adult patients were switched to subcutaneous (SC) administration on recommendation from their physician because of difficulties with venous access and poor control of attacks on intravenous $\mathrm{C} 1$ inhibitor prophylaxis respectively. Due to the severity of $\mathrm{HAE}$ these patients had suffered numerous breakthrough attacks. Physicians considered C1-INH SC to be a more appropriate treatment option in these patients as they felt this would provide better control of the patients' symptoms, particularly due to the smoother PK-PD profile of $\mathrm{SC}$ infusions.

\section{Data collection}

Patient data including age, gender, HAE type and severity, age of diagnosis, and administration details on previous and current treatment were collected. Training procedure (i.e., number of sessions) and time taken to master self-administration was recorded for both $1500 \mathrm{IU}$ and multiple $500 \mathrm{IU}$ vials. Training time did not include training for cannulation, only training time for vial reconstitution. To assess the practicalities of administering C1-INH $\left(\right.$ Berinert $\left.^{\circledR}\right)$, preparation and administration time for both vial formats (1500 IU vs. multiple $500 \mathrm{IU}$ ) was estimated and reported by the patient on several occasions. To assess quality of life patients were asked to complete a self-assessment form and rate in a 5-point Likert scale several aspects of C1-INH (Berinert $\left.{ }^{\circledR}\right) 500$ and 1500 IU. Key challenges raised by patients were also noted.

\section{Data analysis}

In order to assess differences between multiple $500 \mathrm{IU}$ vials and the 1500 IU vial in administration time, training time and each of the rated aspects pairwise comparisons were performed and analyzed with SPSS15.0 statistical package.

\section{Results}

\section{Patient characteristics}

Twenty-three HAE patients aged 10-65 (37.8 \pm 14.7$)$ were assessed. The majority (95.6\%) of the patients had type I HAE, the remainder had type II HAE. Twenty-one patients had previously received treatment with C1-INH $\left(\right.$ Berinert $\left.^{\circledR}\right) 500 \mathrm{IU}$ for a mean duration of $6.4 \pm 3.9$ years $($ range $=1-14)$ prior to switching to C1-INH $\left(\right.$ Berinert $\left.^{\circledR}\right)$ $1500 \mathrm{IU}$. In patients who switched from multiple $500 \mathrm{IU}$ vials to $1500 \mathrm{IU}$ the total dose was not changed. Twenty out of twenty-one patients decreased the number of vials from three C1-INH $\left(\right.$ Berinert $\left.^{\circledR}\right) 500 \mathrm{IU}$ vials to one C1-INH (Berinert $\left.{ }^{\circledR}\right) 1500$ IU vial; one patient switched from four C1-INH (Berinert ${ }^{\circledR}$ ) 500 IU vials to SC administration (3000 IU/dose; two vials). Two patients were naive to C1-INH (Berinert ${ }^{\circledR}$ ) treatment and only received the 1500 IU vial format (see Fig. 1 and Table 2 for detailed information). Although all patients remained stable on C1-INH (Berinert $\left.{ }^{\circledR}\right) 1500 \mathrm{IU}$, two patients switched back to C1-INH (Berinert ${ }^{\circledR}$ ) 500 IU due to headaches and preference for a larger volume.

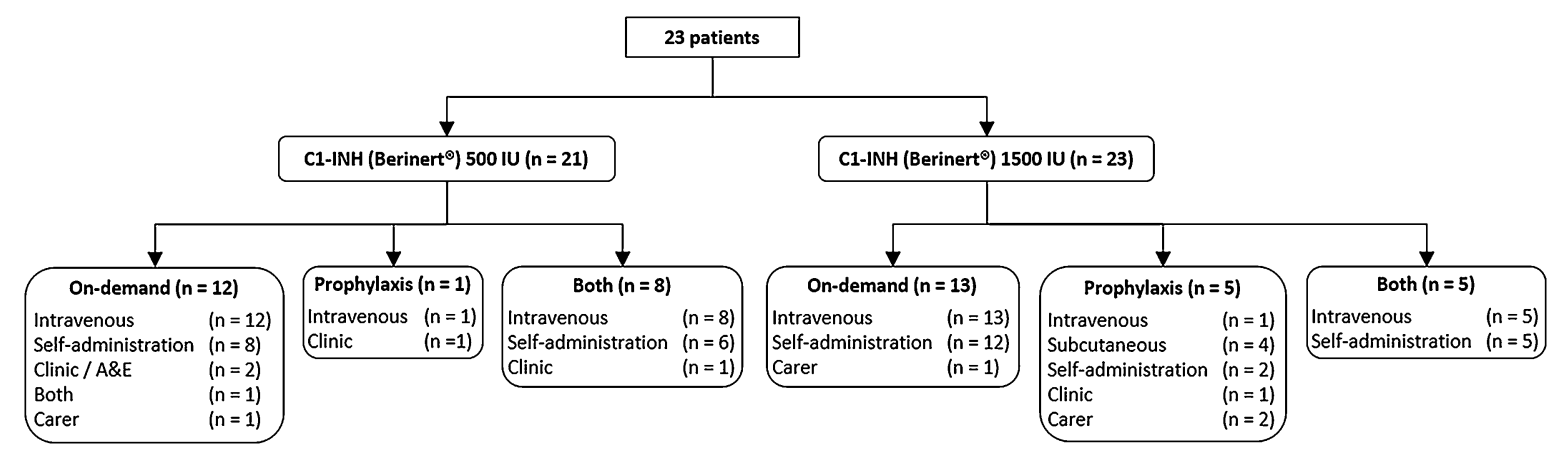

Fig. 1 Patient disposition 
Table 2 Demographics and patients' information

\begin{tabular}{|c|c|}
\hline & $N=23$ \\
\hline Age, years, mean (SD) & $37.8(14.7)$ \\
\hline Female, n (\%) & $17(73.9)$ \\
\hline \multicolumn{2}{|l|}{ HAE } \\
\hline Type I, n (\%) & $22(95.6)$ \\
\hline Type II, n (\%) & $1(4.3)$ \\
\hline \multicolumn{2}{|l|}{ HAE severity ${ }^{a}$} \\
\hline Moderate, n (\%) & $12(52.2)$ \\
\hline Severe, $\mathrm{n}(\%)$ & $11(47.8)$ \\
\hline Other HAE treatment before switching, n (\%) & $23(100)$ \\
\hline Icatibant (alternative to C1-INH for acute attacks) & $12(52.2)$ \\
\hline Danazol (prophylaxis) & $17(73.9)$ \\
\hline Stanozolol (prophylaxis) & $2(8.7)$ \\
\hline Oxandrolone (prophylaxis) & $1(4.3)$ \\
\hline Tranexamic acid (prophylaxis) & $14(60.9)$ \\
\hline Previous treatment with C1-INH (Berinert $\left.{ }^{\circledR}\right) 500 \mathrm{IU}, \mathrm{n}(\%)$ & $21(91.3)$ \\
\hline Adverse effects & $0(0)$ \\
\hline Preparation/infusion time, minutes, mean (SD) $(n=18)$ & $16.9(2.5)$ \\
\hline Training time ${ }^{b}$, minutes, mean $(S D)(n=8)$ & $55.6(6.2)$ \\
\hline Years before switching to $1500 \mathrm{IU}$, mean (SD) & $6.4(3.9)$ \\
\hline Current treatment with C1-INH (Berinert ${ }^{\circledR}$ ) $1500 \mathrm{IU}, \mathrm{n}(\%)$ & $23(100)$ \\
\hline Adverse effects & $1(4.3)$ \\
\hline Preparation/infusion time, minutes, mean $(S D)(n=18)$ & $11.1(2.7)$ \\
\hline Training time ${ }^{b}$, minutes, mean $(S D)(n=6)$ & $45(7.7)$ \\
\hline Years current treatment with 1500 IU, mean (SD) & $1(0.49)$ \\
\hline
\end{tabular}

a Severity scoring criteria [23]

${ }^{\mathrm{b}}$ Not including training for cannulation; $\mathrm{SD}$, standard deviation

\section{Preparation and administration}

Preparation and administration of C1-INH (Berinert ${ }^{\circledR}$ ) $1500 \mathrm{IU}$ was faster than an equivalent dose with multiple
$500 \mathrm{IU}$ vials (mean difference [MD], $-5.8 \mathrm{~min}$; 95\% confidence interval $[\mathrm{CI}],-7.11$ to $-4.55 ; t(17)=-9.62$, $p<0.001$ ) (Fig. 2). Patients reported that reconstitution of the $1500 \mathrm{IU}$ vial was more difficult than that of the $500 \mathrm{IU}$ vial; the former took longer to dissolve and required gentle mixing to fully dissolve C1-INH prior to administration. Despite this, reduced preparation intricacy, i.e., preparation and administration of one vs. three syringes/ vials, no need to pool multiple vials, and lower infusion times demonstrated the superiority of the $1500 \mathrm{IU}$ formulation.

Differences between vial formats in the time to train to self-administer were assessed by comparing a group of patients that had received training with $\mathrm{C} 1-\mathrm{INH}$ (Berinert $\left.^{\circledR}\right) 500 \mathrm{IU}(\mathrm{n}=8)$ to a group of patients naïve to self-administration that received for the first time training with $\mathrm{C} 1-\mathrm{INH}\left(\right.$ Berinert $\left.^{\circledR}\right) 1500 \mathrm{IU}(\mathrm{n}=6)$. Patients required less time to learn to self-administer the $1500 \mathrm{IU}$ format than multiple $500 \mathrm{IU}$ (MD, -10.6 ; CI -18.7 to $-2.5 ; t(12)=-2.85, p<0.015$ ) (Fig. 2). No additional training was required for 14 patients who switched from multiple $500 \mathrm{IU}$ vials to one $1500 \mathrm{IU}$ vial.

\section{Patient perspective}

Sixteen patients who switched from C1-INH $\left(\right.$ Berinert $^{\circledR}$ ) $500 \mathrm{IU}$ to $\mathrm{C} 1-\mathrm{INH}$ (Berinert ${ }^{\circledR}$ ) $1500 \mathrm{IU}$ rated several aspects of each vial format (Table 3). Overall, patients rated C1-INH (Berinert $\left.{ }^{\circledR}\right) 1500 \mathrm{IU}$ higher than $500 \mathrm{IU}$ in all aspects including preparation and administration (Table 3). Patients reported that the administration method was faster to master with the 1500 IU compared with the $500 \mathrm{IU}$ vial size. Patients also rated the preparation and infusion time of a single treatment dose faster with one C1-INH (Berinert ${ }^{\circledR}$ ) 1500 IU compared with

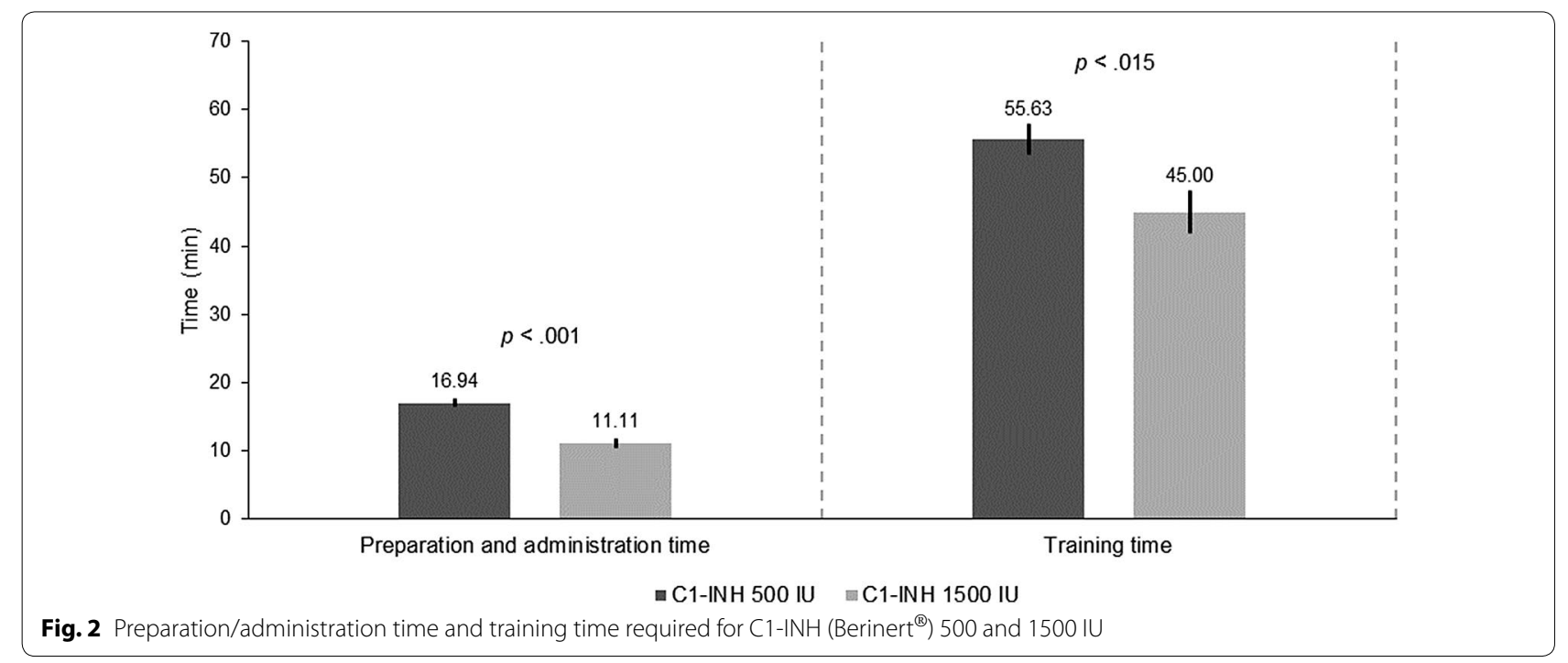


Table 3 Patients' ratings of different aspects of the 500 and $1500 \mathrm{IU}$ vial format

\begin{tabular}{|c|c|c|c|}
\hline Switching patients $(n=16)$ & $500 \mathrm{IU}$ & $1500 \mathrm{IU}$ & $\mathrm{Cl} / \mathrm{t}(15)$ \\
\hline $\begin{array}{l}\text { Thinking about when you were first trained to use C1-INH (Berinert }{ }^{\circledR} \text { ) 500/1500 IU, how would you rate the } \\
\text { experience? (1 very difficult - } 5 \text { very easy) }\end{array}$ & $3.2(1.2)$ & $4.69(0.6)$ & $\begin{array}{l}-2.17 \text { to }-0.83 \\
-4.74^{* * *}\end{array}$ \\
\hline $\begin{array}{l}\text { How would you rate the time it took you to master the administration of one treatment dose with C1-INH } \\
\left.{\left.\text { (Berinert }{ }^{\circledR}\right)}^{(}\right) 500 / 1500 \text { IU vials? (1 very long - 5 very fast) }\end{array}$ & $3.8(1.1)$ & $4.7(0.5)$ & $\begin{array}{l}-1.71 \text { to }-0.67 \\
-4.84^{* * *}\end{array}$ \\
\hline $\begin{array}{l}\text { How would you rate preparation and infusion time of one treatment dose with C1-INH (Berinert }{ }^{\circledR} \text { ) 500/1500 IU } \\
\text { vials? ( } 1 \text { very long - } 5 \text { very fast) }\end{array}$ & $3.1(0.9)$ & $4.2(0.8)$ & $\begin{array}{l}-1.86 \text { to }-0.38 \\
-3.2^{* *}\end{array}$ \\
\hline $\begin{array}{l}\left.\text { How would you rate administration of one treatment dose with C1-INH (Berinert }{ }^{\circledR}\right) 500 / 1500 \text { IU vials? (1 very } \\
\text { hard - } 5 \text { very easy) }\end{array}$ & $3.2(1.3)$ & $4.5(0.5)$ & $\begin{array}{l}-1.88 \text { to }-0.62 \\
-4.23^{* * *}\end{array}$ \\
\hline How would you rate storage convenience of $\mathrm{C} 1$-INH $\left(\right.$ Berinert $\left.^{\circledR}\right)$ 500/1500 IU vials? ( 1 very poor -5 excellent) & $3.2(1.2)$ & $4.9(0.5)$ & $\begin{array}{l}-2.38 \text { to }-0.99 \\
-5.18^{* * *}\end{array}$ \\
\hline How would you rate travel convenience of C1-INH (Berinert $\left.{ }^{\circledR}\right)$ 500/1500 IU vials? (1 very poor -5 excellent) & $2.6(1.0)$ & $4.7(0.4)$ & $\begin{array}{l}-2.75 \text { to }-1.63 \\
-8.36^{* * *}\end{array}$ \\
\hline Overall, how satisfied were you with C1-INH (Berinert ${ }^{\circledR}$ ) 500/1500 IU? (1 very poor-5 excellent) & $3.8(1.1)$ & $4.4(1.1)$ & $\begin{array}{l}-1.62 \text { to }-0.37 \\
\text { n.s }\end{array}$ \\
\hline Naïve patients $(n=2)$ & & $1500 \mathrm{IU}$ & ${ }^{a} \mathrm{Cl} / \mathrm{t}$ \\
\hline $\begin{array}{l}\text { Thinking about when you were first trained to use } \mathrm{C} 1 \text {-INH }\left(\text { Berinert }^{\circledR}\right) \\
\text { ence? ( } 1 \text { very difficult— } 5 \text { very easy) }\end{array}$ & & $3.5(2.1)$ & $\begin{array}{l}-17.09 \text { to } 19.47 \\
\text { n.s }\end{array}$ \\
\hline $\begin{array}{l}\text { How would you rate the time it took you to master the administration of one treatment dose with C1-INH } \\
\left.\text { (Berinert }{ }^{\circledR}\right) 1500 \text { IU vials? (1 very long— } 5 \text { very fast) }\end{array}$ & & $3.5(2.1)$ & $\begin{array}{l}-17.43 \text { to } 19.55 \\
\text { n.s }\end{array}$ \\
\hline $\begin{array}{l}\text { How would you rate preparation and infusion time of one treatment dose with C1-INH (Berinert }{ }^{\circledR} \text { ) } 1500 \text { IU? (1 } \\
\text { very long - } 5 \text { very fast) }\end{array}$ & & $4.0(0.0)$ & $\begin{array}{l}-1.09 \text { to } 1.47 \\
\text { n.s }\end{array}$ \\
\hline $\begin{array}{l}\left.\text { How would you rate administration of one treatment dose with C1-INH (Berinert }{ }^{\circledR}\right) 1500 \text { IU vials? (1 very } \\
\text { hard - } 5 \text { very easy) }\end{array}$ & & $4.5(0.7)$ & $\begin{array}{l}-0.84 \text { to } 0.84 \\
\text { n.s }\end{array}$ \\
\hline How would you rate storage convenience of C1-INH (Berinert ${ }^{\circledR}$ ) 1500 IU vials? (1 very poor - 5 excellent) & & $4.5(0.7)$ & $\begin{array}{l}-0.44 \text { to } 1.19 \\
\text { n.s }\end{array}$ \\
\hline How would you rate travel convenience of $\mathrm{C} 1$-INH (Berinert ${ }^{\circledR}$ ) 1500 IU vials? (1 very poor -5 excellent) & & $5.0(0.0)$ & $\begin{array}{l}-0.94 \text { to } 0.44 \\
\text { n.s }\end{array}$ \\
\hline Overall, how satisfied are you with C1-INH (Berinert $\left.{ }^{\circledR}\right) 1500$ IU? (1 very poor -5 excellent) & & $4.5(0.7)$ & $\begin{array}{l}-1.77 \text { to } 1.64 \\
\text { n.s }\end{array}$ \\
\hline
\end{tabular}

Mean ratings on a 5-point Likert scale. Standard deviation in parenthesis. $\mathrm{Cl} / \mathrm{t}(15)$, confidence interval of the $\mathrm{t}$ test with 15 degrees of freedom

${ }^{* * *} p<0.001 ;{ }^{* *} p<0.01 ;{ }^{*} p<0.05$; n.s not significant

a Switching vs. naïve patients comparison

multiple C1-INH (Berinert ${ }^{\circledR}$ ) 500 IU. Administration of C1-INH (Berinert ${ }^{\circledR}$ ) 1500 IU was also rated as easier. With regards to convenience, C1-INH (Berinert ${ }^{\circledR}$ ) $1500 \mathrm{IU}$ vial was easier to store at home and travel with compared with an equivalent dose of multiple C1-INH (Berinert $\left.^{\circledR}\right) 500 \mathrm{IU}$.

No significant differences in patient attitudes were observed between patients who switched from multiple C1-INH (Berinert $\left.{ }^{\circledR}\right) 500 \mathrm{IU}$ and those who were naïve to C1-INH (Berinert ${ }^{\circledR}$ ) 1500 IU treatment (Table 3).

\section{Subcutaneous, off-label treatment with C1-INH}

Four patients received prophylactic treatment with C1-INH (Berinert ${ }^{\circledR}$ ) 1500 IU via SC injection. Two were pediatric patients (10 year-old males), whose parents administered the subcutaneous treatment, one patient had a dosing regimen of $3000 \mathrm{IU}$ three times a week and the other patient of 1500 IU every 5 days. The other two patients, with severe HAE, self-administered their own treatment, one patient had a fixed dose of $3000 \mathrm{IU}$ three times a week and the other of 3000 IU twice a week. The combined mean preparation and administration time for these patients was 23.75 (7.5) $\mathrm{min}$; this was significantly longer compared with patients that received C1-INH $\left(\right.$ Berinert $\left.^{\circledR}\right) 1500$ IU IV (10.53 (1.58) min; CI -25.09 to $-1.36 ; t(3.06)=-3.51, p<0.038)$. The difference in mean preparation and infusion time between IV and SC administration may be due to dosing differences between IV and SC (1500 / dose vs. 3000 IU/dose, respectively) and slightly longer time required to inject SC compared with IV.

\section{Challenges for treatment with C1-INH}

Patients identified numerous challenges for use of both the C1-INH (Berinert ${ }^{\circledR}$ ) 500 IU and 1500 IU formulations. For the $500 \mathrm{IU}$ vial format the main challenges included the need to carry/utilize multiple vials and change syringes three times during preparation. This 
was especially challenging for patients to perform when feeling unwell. The primary challenge from a patient perspective for C1-INH (Berinert ${ }^{\circledR}$ ) $1500 \mathrm{IU}$ was that it took longer to dissolve and required more careful mixing. One patient who switched back to use of three $500 \mathrm{IU}$ vials due to experiencing headaches with the $1500 \mathrm{IU}$ vial, also reported that the $1500 \mathrm{IU}$ vial was more difficult and took longer to dissolve than the $500 \mathrm{IU}$.

\section{Discussion}

The current study examined the clinical experience with the new C1-INH (Berinert ${ }^{\circledR}$ ) 1500 IU vial presentation compared with multiple 500 IU vials. The 1500 IU vial format was faster to prepare and administer, and training time for self-administration was easier requiring fewer training sessions compared to the $500 \mathrm{IU}$ vial format. Even though patients noted that the $1500 \mathrm{IU}$ vial took longer to dissolve, the new vial format was rated superior in all assessed aspects of the patient self-assessment form compared with multiple 500 IU vials. Only two patients switched back to multiple 500 IU vials; this was due to headaches and patients believing that the $1500 \mathrm{IU}$ vial was not as effective as $(3 \times) 500$ IU vials.

HAE attacks are associated with increased morbidity and mortality [9]. Attacks of swelling affecting the limbs can be disabling (e.g., inability to walk or use hands), and swelling of the face may temporarily disfigure patients, often confining them at home and hampering their work/ schooling, social and personal life. Furthermore, patients with severe and frequent abdominal attacks may require narcotics to manage the excruciating pain; this, if uncontrolled, can lead to a narcotic addiction [9]. Attacks often disrupt patients' life, for instance missing social/family events, impeding travel and leisure activities, increasing absenteeism and reducing productivity, hindering career and educational advancement, even in some cases causing loss of employment $[10,11]$. Furthermore, the constant fear of an attack, with the possibility of asphyxiation, severely impairs all aspects of these patients' quality of life (professional, social, personal, physical and mental) [10-13]. Accordingly, a reduction in attack duration and frequency, and the time to onset of relief has been reported when treatment was administered early and quickly $[14,15]$. This, together with access to medication and the ability to self-administer have a large positive impact on patients' quality of life and mental health (i.e. reducing anxiety and depression) $[10,11,16,17]$. Therefore, effective, easy and fast to administer treatment is needed to allow patients to manage the severity and duration of their HAE attacks.

HAE is a debilitating chronic disorder that inflicts massive strain in patients' life; efforts to lessen any factors contributing to the burden of the disease should be sought. Efforts to improve patients' quality of life have included self-administered C1-INH. Implementation and acceptance of self-administration has been widespread amongst physicians, nurses and patients [18-20]. The results from an online survey reported the experience of ten centers (eight in Europe, one in Canada and one the USA) in implementing and training C1-INH selfadministration [18]. Overall, both patients and clinicians agreed that switching to self-administration significantly improved quality of life, independence and convenience [18]. Self-administration allows patients to take control of their disease; they feel less restricted and, due to the ability to administer treatment quickly when- and wherever required, have a reduced fear of attacks [17, 21]. The Berinert ${ }^{\circledR} 1500 \mathrm{IU}$ vial presentation has been shown here to be easier to learn to self-administer, and as only one vial is needed, it avoids having to change syringes during administration, thus making self-administration even more convenient. Subsequently, attack-related costs derived from travel expenses to the clinic and medication related paraphernalia (i.e., syringes) [10], and environmental costs from multiple non-recyclable packages and materials could be reduced with the 1500 IU vial. In addition some patients have been able to use the $1500 \mathrm{IU}$ vial for SC injection. This may further increase patients' conveniences by providing an alternative prophylactic self-treatment option for patients who find IV administration difficult, have poor venous access or are afraid of IV needles.

One limitation of the present study is the small sample size. While this may weaken the results from the subgroup analyses, this study succeeded in gathering and reporting data from 23 patients with a very rare genetic disorder. Another limitation of the study is that it presents self-reported data gathered using questionnaires. While self-reported data may be subjective and difficult to independently verify, it represents the real-life experience of patients. Furthermore, the combination of qualitative and quantitative data reported are mutually supportive.

\section{Conclusions}

The new C1-INH (Berinert $^{\circledR}$ ) 1500 IU vial presentation is a practical and convenient alternative to the $500 \mathrm{IU}$ formulation for the treatment of HAE. It has demonstrated reduced training and time to treatment (preparation and infusion times) compared with multiple C1-INH $\left(\right.$ Berinert $\left.^{\circledR}\right) 500 \mathrm{IU}$ vials. From a patient perspective the new vial presentation offers a faster and easier to administer treatment, which is more convenient to store and travel with. Therefore, it contributes towards the continued efforts to improve treatment and convenience for HAE patients, further facilitating access to treatment and 
self-administration, which provides patients with more control and independence.

\section{Abbreviations}

HAE: hereditary angioedema; C1-INH: C1 inhibitor; IU: international units; IV: intravenous; SC: subcutaneous; MD: mean difference; $\mathrm{Cl}$ : confidence interval.

\section{Authors' contributions}

JD contributed to the study conception and design, data collection and interpretation, and writing of the manuscript. The author read and approved the final manuscript.

\section{Acknowledgements}

Medical writing assistance was provided by Anna Mestres-Missé of Meridian HealthComms Ltd (Plumley, UK), funded by CSL Behring.

\section{Competing interests}

JD has acted as a consultant for, and received educational grants from Shire and CSL Behring.

\section{Availability of data and materials}

The datasets analyzed during the current study are available from the corresponding author on reasonable request.

\section{Consent for publication}

Not applicable.

\section{Ethics approval and consent to participate}

Not applicable.

\section{Funding}

Not applicable.

\section{Publisher's Note}

Springer Nature remains neutral with regard to jurisdictional claims in published maps and institutional affiliations.

Received: 29 January 2018 Accepted: 23 May 2018

Published online: 25 October 2018

\section{References}

1. Zuraw BL. Clinical practice. Hereditary angioedema. N Engl J Med 2008;359:1027-36.

2. Bork K, Siedlecki K, Bosch S, Schopf RE, Kreuz W. Asphyxiation by laryngeal edema in patients with hereditary angioedema. Mayo Clin Proc. 2000;75:349-54

3. Bork K, Brehler R, Witzke G, Boor S, Heineke W, Hardt J. Blindness, tetraspasticity, and other signs of irreversible brain damage in hereditary angioedema. Ann Allergy Asthma Immunol. 2017;118:520-1.

4. Craig T, Aygoren-Pursun E, Bork K, Bowen T, Boysen H, Farkas H, Grumach $\mathrm{A}$, Katelaris $\mathrm{CH}$, Lockey $\mathrm{R}$, Longhurst $\mathrm{H}$, et al. WAO guideline for the management of hereditary angioedema. World Allergy Organ J. 2012:5:182-99.

5. Farkas H, Jakab L, Temesszentandrasi G, Visy B, Harmat G, Fust G, Szeplak G, Fekete B, Karadi I, Varga L. Hereditary angioedema: a decade of human C1-inhibitor concentrate therapy. J Allergy Clin Immunol. 2007;120:941-7.
6. Waytes AT, Rosen FS, Frank MM. Treatment of hereditary angioedema with a vapor-heated C1 inhibitor concentrate. N Engl J Med. 1996:334:1630-4.

7. Zuraw BL, Busse PJ, White M, Jacobs J, Lumry W, Baker J, Craig T, Grant JA, Hurewitz D, Bielory L, et al. Nanofiltered C1 inhibitor concentrate for treatment of hereditary angioedema. N Engl J Med. 2010;363:513-22.

8. Berinert 500 \& $1500 \mathrm{IU}$. https://www.medicines.org.uk/emc/medic ine/21637. Accessed July 2017.

9. Zuraw BL, Bernstein JA, Lang DM, Craig T, Dreyfus D, Hsieh F, Khan D, Sheikh J, Weldon D, Bernstein DI, et al. A focused parameter update: hereditary angioedema, acquired $\mathrm{C} 1$ inhibitor deficiency, and angiotensin-converting enzyme inhibitor-associated angioedema. J Allergy Clin Immunol. 2013;131:1491-3.

10. Bygum A, Aygoren-Pursun E, Beusterien K, Hautamaki E, Sisic Z, Wait S, Boysen HB, Caballero T. Burden of illness in hereditary angioedema: a conceptual model. Acta Derm Venereol. 2015;95:706-10.

11. Lumry WR, Castaldo AJ, Vernon MK, Blaustein MB, Wilson DA, Horn PT. The humanistic burden of hereditary angioedema: impact on healthrelated quality of life, productivity, and depression. Allergy Asthma Proc. 2010:31:407-14.

12. Longhurst $\mathrm{H}$, Cicardi M. Hereditary angio-oedema. Lancet. 2012:379:474-81.

13. Wilson DA, Bork K, Shea EP, Rentz AM, Blaustein MB, Pullman WE. Economic costs associated with acute attacks and long-term management of hereditary angioedema. Ann Allergy Asthma Immunol. 2010;104:314-20

14. Bork K, Meng G, Staubach P, Hardt J. Treatment with C1 inhibitor concentrate in abdominal pain attacks of patients with hereditary angioedema. Transfusion. 2005:45:1774-84.

15. Levi M, Choi G, Picavet C, Hack CE. Self-administration of C1-inhibitor concentrate in patients with hereditary or acquired angioedema caused by C1-inhibitor deficiency. J Allergy Clin Immunol. 2006;117:904-8.

16. Banerji A, Busse P, Christiansen SC, Li H, Lumry W, Davis-Lorton M, Bernstein JA, Frank M, Castaldo A, Long JF, et al. Current state of hereditary angioedema management: a patient survey. Allergy Asthma Proc. 2015:36:213-7.

17. Longhurst HJ, Carr S, Khair K. C1-inhibitor concentrate home therapy for hereditary angioedema: a viable, effective treatment option. Clin Exp Immunol. 2007;147:11-7.

18. Caballero T, Sala-Cunill A, Cancian M, Craig TJ, Neri S, Keith PK, BocconGibod I, Bethune C, Bork K. Current status of implementation of selfadministration training in various regions of Europe, Canada and the USA in the management of hereditary angioedema. Int Arch Allergy Immunol. 2013;161(Suppl 1):10-6.

19. Symons C, Rossi O, Magerl M, Andritschke K. Practical approach to selfadministration of intravenous $\mathrm{C} 1-\mathrm{INH}$ concentrate: a nursing perspective. Int Arch Allergy Immunol. 2013;161(Suppl 1):17-20.

20. Boysen HB, Bouillet L, Aygoren-Pursun E. Challenges of C1-inhibitor concentrate self-administration. Int Arch Allergy Immunol. 2013;161(Suppl 1):21-5.

21. Bygum A, Andersen KE, Mikkelsen CS. Self-administration of intravenous C1-inhibitor therapy for hereditary angioedema and associated quality of life benefits. Eur J Dermatol. 2009:19:147-51.

22. Cicardi M, Aberer W, Banerji A, Bas M, Bernstein JA, Bork K, Caballero T, Farkas H, Grumach A, Kaplan AP, et al. Classification, diagnosis, and approach to treatment for angioedema: consensus report from the hereditary angioedema international working group. Allergy. 2014;69:602-16.

23. Prior N, Remor E, Perez-Fernandez E, Caminoa M, Gomez-Traseira C, Gaya F, Aabom A, Aberer W, Betschel S, Boccon-Gibod I, et al. Psychometric field study of hereditary angioedema quality of life questionnaire for adults: HAE-QoL. J Allergy Clin Immunol Pract. 2016;4(464-473):e464. 